HORTICULTURE

\title{
Optimization of Spacing, doses of Vermi-compost and Foliar Application of Salicylic Acid on Growth, Flowering and Soil Health of Chrysanthemum (Dendranthema grandiflora Tzvelev) cv. "Guldasta"
}

\author{
Aashutosh, Mukesh Kumar*1, Sunil Malik ${ }^{1}$, Manoj Kumar Singh ${ }^{1}$, \\ S.P. Singh ${ }^{2}$, Veena Chaudhary ${ }^{3}$ and V.R. Sharma ${ }^{4}$ \\ ${ }^{1}$ Department of Horticulture, SVPUAT, Meerut, Uttar Pradesh, India \\ ${ }^{2}$ Department of Soil Science, SVPUAT, Meerut, Uttar Pradesh, India \\ ${ }^{3}$ Department of Chemistry, Meerut College Meerut, Uttar Pradesh, India \\ ${ }^{4}$ CSIR-National Botanical Research Institute, Lucknow, Uttar Pradesh, India
}

"Corresponding author: k.mukesh123@yahoo.com (ORCID ID: 0000-0003-4539-9732)

Paper No. 786

Received: 08-04-2019

Revised: 10-07-2019

Accepted: 22-08-2019

\begin{abstract}
A field experiment was conducted during the year 2018-2019 to study the effect of spacing $(50 \times 50,50 \times 60$ and $50 \times 75)$, dose of vermi-compost (0, 5.0 and 10.0 ton/ha) and foliar application of salicylic acid $(0,100$ and $200 \mathrm{ppm}$ ) on the growth, flowering and soil health of chrysanthemum. The experiment was laid out in a factorial randomized block design with twenty seven treatments and three replications. Significant improvement in growth and flowering characters was recorded with closer spacing $(50 \times 50 \mathrm{~cm})$ except plant spread, number of flowers/plant, weight of individual flower, diameter of flower, shelf life and stalk length while, plants grown at wider spacing had maximum available NPK in post harvested soil. Gradual increases doses of vermicompost for 0 to 10.0 ton/ha significantly improved plant growth, flowering and yield attributing traits alongwith higher availability of NPK in post harvested soil. Among the foliar spray of salicylic acid, salicylic acid (100 ppm) significantly produced good plant growth and flower yield except induced early flowering and 50\% flowering however, control showed maximum availability of NPK in post-harvested soil. Among the combined combinations, maximum flower yield/plant was recorded with treatment combination $\mathrm{T}_{26}\left(\mathrm{~S}_{3}+\mathrm{VC}_{2}+\mathrm{SA}_{1}\right)$ and treatment combination $\mathrm{T}_{8}\left(\mathrm{~S}_{1}+\mathrm{VC}_{2}+\mathrm{SA}_{1}\right)$ resulted in maximum flower yield/plot and flower yield/ha during course of study.
\end{abstract}

\section{Highlights}

(0) The closer spacing showed $(50 \times 50 \mathrm{~cm})$ gave maximum plant height and flowering yield/ha while wider spacing $(50 \times 75 \mathrm{~cm})$ resulted in maximum plant spread, number of flowers/plant, weight of individual flower, diameter of flower, shelf-life and stalk length.

( Gradual increases doses of vermicopost had maximum plant growth, flower yield and higher availability of NPK in post-harvested soil.

( ) An application of salicylic acid @ (100 ppm) significantly produced good plant growth and higher flower yield except induced early flowering and 50\% flowering however, control showed maximum availability of NPK in post-harvested soil.

( Combined effect of different treatments, maximum flower yield/plant (162.39 g) was recorded with treatment combination $\mathrm{T}_{26}\left(\mathrm{~S}_{3}+\mathrm{VC}_{2}+\mathrm{SA}_{1}\right)$. However, treatment combination $\mathrm{T}_{8}\left(\mathrm{~S}_{1}+\mathrm{VC}_{2}+\mathrm{SA}_{1}\right)$ resulted in maximum flower yield/plot $(4.87 \mathrm{~kg})$ and flower yield (3.79 ton $/ \mathrm{ha})$.

Keywords: chrysanthemum, spacing, vermicompost, salicylic acid, growth and flowering 
Chrysanthemum (Dendranthema grandiflora Tzvelev) is a leading commercial crop grown for cut loose flowers and also as a pot plant (Navale et al. 2010). Chrysanthemum is one of the more popular flowers grown in our country for its diversified beauty of colours, shapes, shades and keeping quality. Flowers of standard varieties are produced on long, sturdy stems and have a good keeping quality. These characters make it highly suitable for flower arrangements. Flower of spray varieties are highly suitable as loose flower for making Garland, Veni and Gajara. It is highly suitable for beds, pots and floral arrangement. Its bloom last over a short period of 1 to 2 months. Hence, they command and give remunerative price in the market. On account of its good keeping quality, chrysanthemum flowers can be transported to a distant market easily.

Optimum spacing plays a significant role to increase the higher production of flower and flower yield (Critto et al. 1980). Besides spacing, doses of vermicompost have been recognized as an effecting means for improving soil aggregation structure, fertility and enhancing microbial diversity, moisture holding capacity of soil and crop yield (Zink and Allen 1998; Barakan et al. 1995).Vermi-composting, through earthworm, is an important and eco-friendly process that transform energy rich and complex organic substances in to stabilized vermi-compost (Bentize et al. 2000). The use of vermi-compost improved soil structure, texture and enhanced soil fertility (Follet et al. 1981).

There are few chemical substances capable of inducing flowering in individual plants. Gibberellins, ethylene and cytokinins are all known to induce flowering in one or more plants (Charles and Tanaka 1979). The plant growth regulators like salicylic acid also play an effective role in the regulation of certain events in flowering of plants (Raskin 1992). It may help to regulate several plant functions, including systemic acquire resistance to pathogens and the formation of flowers. It has also been reported that salicylic acid induce flowering in several species of Lemnaceae (Cleland et al. 1974; Cleland et al. 1982). There are few reports on effect of salicylic acid on plant growth and flowering (Martinez et al. 2004; Jabbarzadeh et al. 2009). This investigation was carried out to evaluate the effect of spacing, doses of vermi-compost and foliar application of salicylic acid on growth, flowering and soil health of
Chrysanthemum (Dendranthema grandiflora Tzvelev.) cv. Guldasta.

\section{MATERIALS AND METHODS}

The present investigation was carried out at Horticultural Research Centre (HRC), Sardar Vallabhbhai Patel University of Agriculture of technology, Meerut (U.P.) during 2018-19 to assess the effect of spacing, doses of vermi-compost and foliar feeding of salicylic acid on optimization of growth and flowering of chrysanthemum (Dendranthema grandiflora Tzvelev.) cv. Guldasta. The experiment was laid out in a factorial randomized block design with twenty seven treatments and three replications. Fully rooted cutting were planted at various spacing i.e. $50 \times 50,50 \times 60$ and $50 \times 75 \mathrm{~cm}$, doses of vermi-compost ( 0,5 and 10 ton/ha) was applied before transplanting of crop and salicylic acid spray was applied in the range of 0,100 and 200 ppm after 20 and 40 days after transplanting of rooted cutting. The basic recommended doses of inorganic fertilizers i.e. $120 \mathrm{~kg} \mathrm{~N}$ (half dose at the time of transplanting and half doses after 25 and 40 days after transplanting) and full dose of $80 \mathrm{~kg} \mathrm{P}_{2} \mathrm{O}_{5}$ and $80 \mathrm{~kg} \mathrm{~K} \mathrm{O}_{2} \mathrm{O}$ applied uniformly for all the treatments at the time of planting. The cultural practices like irrigation, hoeing, weeding and plant protection measures were done as required by the crop. The vegetative and flowering parameters were recorded during the period of crop while soil parameters were analyzed before and after harvesting the crops. The data was analyzed at $5 \%$ level of significance using OPSTAT statistical software. The experiment field soil and compost were tested in laboratory for their different physicchemical parameters (Table $1 \& 2$ ).

Table 1: General soil properties $(0-20 \mathrm{~cm})$ before the experiment started in 2017

\begin{tabular}{ccc}
\hline Parameter & Mean & C.V. ${ }^{\mathrm{b}}(\%)$ \\
\hline TOC $\left(\mathrm{g} \mathrm{kg}^{-1}\right)$ & 7.44 & 6.02 \\
Total $\left.\mathrm{g} \mathrm{kg}^{-1}\right)$ & 0.93 & 3.02 \\
Olsen-P $\left(\mathrm{mg} \mathrm{kg}^{-1}\right)$ & 9.57 & 15.66 \\
Available $\mathrm{K}^{\mathrm{a}}\left(\mathrm{mg} \mathrm{kg}^{-1}\right)$ & 191 & 3.30 \\
Total porosity (\%) & 49.6 & 5.8 \\
Bulk density $\left(\mathrm{g} \mathrm{cm}^{-3}\right)$ & 1.35 & 3.70 \\
Parameter & Mean & C.V. ${ }^{\mathrm{b}}(\%)$ \\
\hline
\end{tabular}

Note: mean values of parameters in the table were calculated from data for all experimental plots.

${ }^{a}$ Available $\mathrm{K}$ was extracted with $1 \mathrm{M} \mathrm{NH_{4 } A C ;}{ }^{b} \mathrm{C} . V$ : is coefficient of variation. 


\section{Preparation of vermicompost}

The vermicompost (with earthworm E. eugeniae) produced by a mixture of different individual organic wastes i.e. wastes of vegetables and fruits with cattle manure in the ratio of $10: 1$ on dry weight basis. All experimental sets were maintained with moisture content of about $70-80 \%$ by daily sprinkling of water and terminated after 16 weeks by removing earthworms manually in vermicompost sets. The nutrients of vermicompost are presented in (Table 2).

Table 2: Physio-chemical properties of Vermicompost

\begin{tabular}{cc}
\hline Parameters & Vermicompost \\
\hline $\mathrm{pH}$ & 7.86 \\
Organic carbon & $290.00 \mathrm{~g} / \mathrm{kg}$ \\
Nitrogen \% & 1.38 \\
Phosphorus \% & 0.80 \\
Potash \% & 1.20 \\
Ext.. $\mathrm{Cu}(\mathrm{mg} / \mathrm{kg})$ & 0.88 \\
Ext.. $\mathrm{Zn}(\mathrm{mg} / \mathrm{kg})$ & 275.00 \\
Ext. $\mathrm{Fe}(\mathrm{mg} / \mathrm{kg})$ & 9.20 \\
Ext.. $\mathrm{Mn}(\mathrm{mg} / \mathrm{kg})$ & 12.80 \\
Exch. $\mathrm{Na}(\mathrm{g} / \mathrm{kg})$ & 6.80 \\
Exch. $\mathrm{Ca}(\mathrm{g} / \mathrm{kg})$ & 18.80 \\
Exch. $\mathrm{Mg}(\mathrm{g} / \mathrm{kg})$ & 5.8 \\
\hline
\end{tabular}

Ext. - Extractable, Exch. - Exchangeable.

Estimation of physio-chemical analysis of soil and vermicompost: A set of five soil $(0-20 \mathrm{~cm}$ depth) samples were taken from each plot and pooled together. The samples were stored at $4{ }^{\circ} \mathrm{C}$ for further physio-chemical analysis. Soil porosity was measured using tension table method as per the procedure explained by (Vomocil 1965). Bulk density of soil was measured by core sampler method developed by (Blake 1965)]. Vermicompost were collected in polythene bags and analyzed for physico-chemical parameters to know the nutrient status. The $\mathrm{pH}$ was measured) in $1 / 10(\mathrm{w} / \mathrm{v})$ aqueous solution (deionized water) using digital $\mathrm{pH}$ meter (Systronic made. The organic carbon was determined by the partially-oxidation method (Walklay and Black 1934). Total N was analyzed using a Kjeldahl digestion method (Jackson 1967) while total P and $\mathrm{K}$ were determined using a wet digestion (Di-acid digestion) method as described earlier (Prasad et al. 2006). Exchangeable $\mathrm{Na}, \mathrm{Ca}$ and $\mathrm{Mg}$ were determined after extracting the sample using ammonium acetate (Simard, 1993) and analyzed by using atomic absorption spectrophotometry (AAS, Perkin-Elmer A Analyst 100). Metals were determined by DTPA (diethylenetriaminepentaacetatic acid) extraction method. $10 \mathrm{gm}$ of air-dried soil was taken in a 50 $\mathrm{ml}$ conical flask and $20 \mathrm{ml}$ of the DTPA extracting solutions was added to it. The solution was extracted on a horizontal shaker for two hours. After exactly two hours of shaking, suspension was filtered by gravity through Whatmann No.42 filter paper. The filtrate was analyzed for $\mathrm{Cu}, \mathrm{Zn}, \mathrm{Fe}$ and Mn subjected for using AAS.

\section{RESULTS AND DISCUSSION}

\section{Impact of spacing doses of vermicompost and foliar application of salicylic acid on growth and flowering of chrysanthemum}

It is clear from (Table 3) that all the vegetative and flowering characters were significantly influenced by various spacing, doses of vermicompost and foliar application of salicylic acid. The data showed that the maximum plant height $(62.26 \mathrm{~cm})$ was recorded under the treatment $S_{1}(50 \times 50 \mathrm{~cm})$ while minimum height of the plant $(60.55 \mathrm{~cm})$ exhibited by wider spacing $(50 \times 75) \mathrm{cm}$. At closer spacing more plant height might be due to heavy competition between plants for light resulted in elongation of main stem and also might be due to the fact that the plants tend to grow vertically when they are crowded owing to shadowing effect of the plants on one another. These results were in accordance with the findings of Karavadia and Dhaduk (2002) in annual chrysanthemum and Shivakumar (2000) in marigold. Maximum plant spread plant $(35.05 \mathrm{~cm})$, number of primary branches (21.35) and number of secondary branches $(26.92 \mathrm{~cm})$ were recorded at wider spacing $(50 \times 75)$ whereas, minimum plant spread $(33.03 \mathrm{~cm})$, number of primary branches (19.77) and number of secondary branches (24.45) were recorded with closer spacing $(50 \times 50 \mathrm{~cm})$. The favorable effect of wider spacing in promoting plant growth might be due to that the wider spacing seems to have helped to the individual plant to utilize more soil, water, nutrition, air and light to help to put up better growth than those having closer spacing, where the plant population per unit area has increased. Similar results have been 
Table 3: Impact of spacing, doses of vermi-compost and foliar application of salicylic acid on growth and flowering of chrysanthemum

\begin{tabular}{|c|c|c|c|c|c|c|c|c|}
\hline Treatment & $\begin{array}{c}\text { Plant } \\
\text { height } \\
\text { (cm) }\end{array}$ & $\begin{array}{l}\text { Plant } \\
\text { spread } \\
\text { (cm) }\end{array}$ & Number of & ranches/plant & $\begin{array}{l}\text { Days to } \\
\text { first bud } \\
\text { initiation }\end{array}$ & $\begin{array}{c}\text { Days to } 50 \% \\
\text { flowering }\end{array}$ & $\begin{array}{c}\text { Shelf-life } \\
\text { (hrs) }\end{array}$ & $\begin{array}{l}\text { Stalk length } \\
\quad(\mathrm{cm})\end{array}$ \\
\hline Spacing $(\mathrm{cm})$ & & & $\begin{array}{l}\text { Primary } \\
\text { branches }\end{array}$ & $\begin{array}{c}\text { Secondary } \\
\text { branches }\end{array}$ & & & & \\
\hline$S_{1}(50 \times 50)$ & 62.26 & 33.03 & 19.77 & 24.45 & 68.84 & 100.58 & 47.70 & 5.06 \\
\hline$S_{2}(50 \times 60)$ & 61.35 & 33.64 & 20.40 & 26.03 & 67.05 & 98.86 & 48.32 & 5.20 \\
\hline $\mathrm{S}_{3}(50 \times 75)$ & 60.55 & 35.05 & 21.35 & 26.92 & 65.41 & 97.23 & 49.00 & 5.36 \\
\hline \multicolumn{9}{|c|}{ Vermi-compost (ton/ha) } \\
\hline $\mathrm{VC}_{0}(0)$ & 59.54 & 32.71 & 19.42 & 24.04 & 70.30 & 101.43 & 47.10 & 4.93 \\
\hline $\mathrm{VC}_{1}(5)$ & 61.68 & 34.14 & 20.62 & 26.46 & 66.16 & 98.18 & 48.55 & 5.27 \\
\hline $\mathrm{VC}_{2}(10)$ & 62.93 & 34.86 & 21.48 & 26.91 & 64.84 & 97.07 & 49.38 & 5.41 \\
\hline \multicolumn{9}{|c|}{ Salicylic acid (ppm) } \\
\hline $\mathrm{SA}_{0}(0)$ & 58.20 & 32.29 & 18.94 & 23.45 & 72.88 & 104.16 & 44.92 & 4.54 \\
\hline $\mathrm{SA}_{1}(100)$ & 63.32 & 34.90 & 21.55 & 27.29 & 64.44 & 96.48 & 50.14 & 5.56 \\
\hline $\mathrm{SA}_{2}(200)$ & 62.64 & 34.53 & 21.03 & 26.67 & 63.97 & 96.04 & 49.97 & 5.51 \\
\hline $\mathrm{CD}$ at $5 \%$ & 0.07 & 0.016 & 0.032 & 0.032 & 0.051 & 0.044 & 0.064 & 0.008 \\
\hline
\end{tabular}

reported by Vinayak et al. (2017) in salvia. Minimum days required for first bud initiation (65.41 days) and days 50\% flowering ( 97.23 days) were recorded at wider spacing $(50 \times 75)$ while, closer spacing $(50 \times 50 \mathrm{~cm})$ induced later bud initiation (68.84 days) and $50 \%$ flowering (100.58 days) respectively. The favorable effect of wider spacing inducing early flowering might be due to more space available to the plants to absorbed more nutrients from soil for better growth and development of plants. The other apparent reason may be due to less competition to plants at wider spacing as results reduced shading effect and increased open area for better light exposure. The same feature holds good for soil moisture availability at wider spacing. Similar results were also reported by Kour (2009) in chrysanthemum and Pal et al. (2015) in gladiolus. Maximum shelf life (49hrs) and stalk length (5.36 $\mathrm{cm})$ was recorded with wider spacing $(50 \times 75)$ on the other hand closer spacing $(50 \times 50 \mathrm{~cm})$ resulted in minimum shelf-life ( $47.70 \mathrm{hrs}$ ) and stalk length $(5.06 \mathrm{~cm})$. The beneficial effect of wider spacing on the shelf life and stalk length may be due to reduced shading effect and increased open area for better light exposure and extraction of more nutrients under wider spacing of plants (Khalaj et al. 2012; Dorajeerao and Mokashi 2013; Bhande et al. 2015).

Various doses of vermi-compost ( 0 - 10 ton/ha) had significant effect on growth and flowering parameters of chrysanthemum. Treatment $\mathrm{VC}_{2}(10$ ton/ha) resulted in maximum height of the plant $(62.93 \mathrm{~cm})$, plant spread $(34.86 \mathrm{~cm})$, number of primary branches (21.48) and number of secondary branches (26.91) while minimum plant height (59.54 $\mathrm{cm})$, plant spread $(32.71 \mathrm{~cm})$, number of primary branches (19.42) and number of secondary branches (24.04) were noted with control. The favorable effect of vermi-compost to increased vegetative growth in chrysanthemum plants might be due to soil built-up organic carbon, improve nutrient status, and enhance cation exchange capacity, microbial activities, microbial biomass carbon and enzymatic activities. The earthworms' castings also have pest repellent attributes. Beside that vermicompost also improves soil structure, soil aggregation and improve water retention capacity (Kumar et al. 2018). Neilsan (1985) reported that the presence of plant growth promoting compound elaborated by earthworm promote a significantly increase in plant growth and N uptake. Sainz et al. (1998) reported that the beneficial effect of vermi-compost on plants might be due to the addition of vermicompost to soil resulted in increase mineral content in substrate and higher concentration of $\mathrm{P}, \mathrm{Ca}, \mathrm{Mg}$, $\mathrm{Cu}, \mathrm{Mn}$ and $\mathrm{Zn}$. Another favorable effect of vermicompost may be due to after application into soil, the plant growth bacteria (PGB) directly stimulate 
growth through nitrogen fixation and plant growth stimulates (Han et al. 2005). The results are close conformity with the findings of Maniram et al. (2012) in gladiolus. The plant receiving $\mathrm{VC}_{2}$ (10 ton/ha) emerged earlier flower bud initiation (64.84 days) and 50\% flowering (97.07 days) while control took maximum days to flower bud initiation (70.30 days) and 50\% flowering (101.43 days) respectively. It may also be due to increase in absorptive surface area of the roots might have led to enhanced uptake and translocation of available water and nutrients like $\mathrm{P}, \mathrm{Zn}, \mathrm{Fe}, \mathrm{Mg}$ and $\mathrm{Cl}$, ultimately resulting in better sink for faster mobilization of photosynthesis and early transformation of plant parts from vegetative to reproductive phase. Similar results were also reported by Singh et al. (2012) in marigold, Singh et al. (2010) in chilli, Singh et al. (2013) in gladiolus; Kumar (2014) in gladiolus; Kumar, (2014) in tuberose; Tiwari et al. (2018 b) in marigold. The treatment $\mathrm{VC}_{2}$ (10 ton/ha) had maximum shelf life $(49.38 \mathrm{hrs})$ and stalk length $(5.41 \mathrm{~cm})$ while minimum shelf life (47.10 hrs) and stalk length (4.93 $\mathrm{cm})$ was registered with control. The best effect of vermicompost had been registered for increasement of number of florets and these florets indirectly increase shelf life of flowers. Increase shelf life and stalk length might be due to increased more uptake of nutrient by plant and greater development of water conducting tissues. Similar results were also reported by Bhalla et al. (2007) in carnation and Maniram et al. (2012) in gladiolus.

As far as concentrations of salicylic acid, maximum height of the plant $(63.32 \mathrm{~cm})$, plant spread (34.90 $\mathrm{cm})$, number of primary branches (21.55) and number of secondary branches (27.29) were recorded with salicylic acid @ 100ppm, which continuously decreased with@ 200 ppm and control respectively. It is due to that application of salicylic acid on plant decreased ethylene production and stimulated plant growth (Sarek 1992). Similar findings have been reported by Kamkari et al. (2016) in marigold. Flowering character like minimum days required for first bud initiation (63.97 days) and days for $50 \%$ flowering (96.04 days) were recorded with 200 ppm of salicylic acid while control took more days for flower bud initiation (72.88) and 50\% flowering (104.16). Earlier floral bud initiation has also been induced by salicylic acid concentrations because this stimulating agent accelerates biosynthesis of secondary metabolites. SA as a manager of blooming time, interacts with both photoperiod-dependent and self-governing pathways. The favorable effect of salicylic acid deficient plant displayed a late flowering due to high based expression of FLC gene Martinez et al. (2004) and decreasing the duration of first flower opening might be due to the given emergence of floral bud Khurama and Cliland (1992). These results were in conformity with Hayat and Ahmad (2007); Hayat et al. (2010) who had reported similar results. The findings are in line with Martin et al. (2005) in African violates. The maximum shelf life of flower (50.14 days) was found under the treatment SA 1 (100 ppm), which decreased (49.97 days) with $\mathrm{SA}_{2}$ (200 ppm) and control attained minimum shelf life (44.92 days). Salicylic acid has great impact on sustaining shelf life in flowering plants particularly equitable interrupted in flowering anatomy. Adding together of small quantity of compound salicylic acid postponed time of senescence, while large amount brought prompt changes by mean of abscission as well as induced senescence in lupine cut flower (Mackay et al. 2000). Similar results were also reported by Al-hasnawi et al. (2019) in gladiolus, Rahmania et al. (2015) in gladiolus and Roodbaraky et al. (2012) in carnation. Maximum length of stalk $(5.56 \mathrm{~cm}$.) was recorded with application of salicylic acid@100 ppm and control produced minimum stalk length $(4.54 \mathrm{~cm})$. Salicylic acid plays an important role in flower stalk length, due increasing stem elongation. The stalk length increased as level précised of salicylic acid, since cell elongation and cell expansion occurred (Raskin 1992). Khandaker et al. (2011) also observed significant increasement in stalk length of Red Amaranthus by foliar application of SA as compared to control plants.

\section{Effect of spacing, doses of vermicompost and foliar application of salicylic acid on qualitative characters of chrysanthemum}

The data revealed (Table 4) that different spacing showed significant differences among the qualitative traits of chrysanthemum. Wider spacing $(50 \times 75$ $\mathrm{cm})$ resulted in maximum number of flowers/ plant $(47.61)$ while closer spacing $(50 \times 50 \mathrm{~cm})$ showed minimum number of flowers/plant (46.16). The beneficial effect of wider spacing on more production of flowers may be due to reduced 
Table 4: Impact of spacing, doses of vermi-compost and foliar application of salicylic acid on qualitative traits of chrysanthemum

\begin{tabular}{|c|c|c|c|c|c|c|c|}
\hline $\begin{array}{c}\text { Treatment } \\
\text { Spacing (cm) }\end{array}$ & \multicolumn{2}{|c|}{ Number of flowers } & $\begin{array}{c}\text { Diameter } \\
\text { of flower } \\
(\mathrm{cm})\end{array}$ & $\begin{array}{l}\text { Weight of } \\
\text { individual } \\
\text { flower (g) }\end{array}$ & $\begin{array}{c}\text { Flower yield/ } \\
\text { plant(g) }\end{array}$ & $\begin{array}{c}\text { Flower yield/ } \\
\text { plot(kg) }\end{array}$ & $\begin{array}{l}\text { Total flower } \\
\text { yield(ton } / \mathrm{h} \text { ) }\end{array}$ \\
\hline$S_{1}(50 \times 50)$ & 46.16 & $1,661.40$ & 5.24 & 2.12 & 107.27 & 3.86 & 2.99 \\
\hline$S_{2}(50 \times 60)$ & 46.95 & $1,408.64$ & 5.41 & 2.21 & 117.16 & 3.51 & 2.73 \\
\hline \multicolumn{8}{|c|}{ Vermi-compost (ton/ha) } \\
\hline $\mathrm{VC}_{0}(0)$ & 45.11 & $1,350.46$ & 5.06 & 1.85 & 98.62 & 2.93 & 2.27 \\
\hline $\mathrm{VC}_{1}(5)$ & 47.54 & $1,423.11$ & 5.51 & 2.28 & 122.85 & 3.64 & 2.83 \\
\hline $\mathrm{VC}_{2}(10)$ & 48.07 & $1,439.13$ & 5.64 & 2.49 & 129.12 & 3.83 & 2.98 \\
\hline $\mathrm{SA}_{2}(200)$ & 48.59 & $1,453.87$ & 5.70 & 2.41 & 132.20 & 3.92 & 3.04 \\
\hline CD at $5 \%$ & 0.028 & 1.083 & 0.009 & 0.007 & 0.386 & 0.011 & 0.009 \\
\hline
\end{tabular}

shading effect and increased open area for better light exposure and more extraction of nutrient for plants (Khalaj et al. 2012; Dorajeerao and Mokashi, 2013; Bhande et al. 2015). This may also be due to less competition among the plants for proper space, light and nutrition. Similar findings have been reported by Baboo et al. (2005) in marigold, Dorajeerao and Mokashi (2013) in chrysanthemum. Closer spacing $(50 \times 50 \mathrm{~cm})$ had the maximum number of flowers/ plot (1661.40) and wider spacing gave minimum number of flowers/plot (1142.66). It could be attributed to accommodation of more number of plants per unit area. Similar results have also been reported by Barman and Pal, (1999) in chrysanthemum. Maximum flower diameter (5.58 $\mathrm{cm})$ was noted with wider spacing $(50 \times 75 \mathrm{~cm})$ whereas, plant spaced at closer spacing $(50 \times 50 \mathrm{~cm})$ exhibited minimum diameter of flower $(5.24 \mathrm{~cm})$. The increase in flower diameter at wider spacing could be attributed to availability of greater space and light for photosynthesis with higher availability and uptake of nutrients by plants which could have enhanced cell division, cell elongation as well as protein synthesis and greater accumulation of dry matter in larger sized sink (flower). The results are close conformity with Pal and Pandey, (2007) and Maniram et al. (2012, a and b) in gladiolus and Singh et al. (2015 a and b) in marigold. Flower yield parameters showed significant differences among the spacing. Maximum weight of individual flower (2.29 $\mathrm{gm})$ was recorded with wider spacing $(50 \times 75$ $\mathrm{cm})$ and minimum weight of individual flower $(2.12 \mathrm{~g})$ was registered with control. The significant increase in weight of individual flower under the wider spacing may be due to less competition among the plants for soil, water, nitrogen, air and light. The increase in weight of individual flower at a wider spacing is in complete agreement with the work done by Kour (2009) in chrysanthemum. Srivastava et al. (2002) also found reduced weight of individual flower in marigold at the closer spacing as compared to wider spacing. Maximum flower yield/plant $(126.17 \mathrm{~g})$ gave by wider spacing $(50 \times 75$ $\mathrm{cm}$ ) while the plants spaced at closer spacing had minimum flower yield/plant (107.27g) respectively. The increase in flower yield/plant at wider spacing could be attributed to availability of greater space and light for photosynthesis with higher availability and uptake of nutrients by plants which could have enhanced cell division, cell elongation as well as protein synthesis and greater accumulation of dry matter in larger sized sink (flower). The increase of the yield of flower per plant at wider spacing is in complete agreement with the work done by Beniwal et al. (2005) in chrysanthemum. The plants spaced at closer spacing $S_{1}(50 \times 50 \mathrm{~cm})$ gave maximum flower yield per plot $(3.86 \mathrm{~kg})$ whereas, wider 
spacing gave minimum flower yield/ plot $(3.03 \mathrm{~kg})$. Similarly, total flower yield ( $\mathrm{q} / \mathrm{ha}$ ) differed each other among spacing and closer spacing $S_{1}(50 \times 50$ $\mathrm{cm}$ ) had maximum flower yield (2.99 ton/ha) while plants spaced at wider spacing $S_{3}(50 \times 75 \mathrm{~cm})$ gave minimum total flower yield (2.35 ton/ha). It could be attributed to accommodation of more number of plants per unit area ultimately increased the flower yield/plot as well as total flower yield/ha. Similar results have also been reported by Barman and Pal (1999) in chrysanthemum.

Different doses of vermicompost showed significant differences among the qualitative traits of chrysanthemum. Maximum number of flowers per plant (48.07) and number of flower per plot (1439.13) were recorded with 10 ton/ha of vermi-compost while, control $\left(\mathrm{VC}_{0}\right)$ resulted in minimum number of flowers/plant (45.11) and number of flowers/plot (1350.46). The increase in number of flower with increase doses of vermi-compost might be due to that after incorporated of vermi-compost produce good plant growth which enhances the process of more photosynthesis in plants (Tomati et al. 1988). These finding were conformity with Padaganur et al. (2005) in tuberose, Kumar (2015) in gladiolus.

The treatment $\mathrm{VC}_{2}$ (10 ton/ha) produced larger size flower $(5.64 \mathrm{~cm})$ while control $\left(\mathrm{VC}_{0}\right)$ gave smaller size flower $(5.06 \mathrm{~cm})$. Treatment $\mathrm{VC}_{2}$ was registered with in maximum weight of individual flower $(2.49 \mathrm{~g})$, flower yield per plant (129.12 g), flower yield per plot $(3.83 \mathrm{~kg})$ and total flower yield (2.98 ton/ha) whereas, the plants grown without any vermicompost (control) had smaller flower (5.06 $\mathrm{cm})$, minimum weight of individual flower (1.85 g), flower yield per plant (98.62 g), flower yield per plot $(2.93 \mathrm{~kg})$ and total flower yield (2.27 ton/ ha) respectively. It might be due to increase the vegetative growth of plants that produced more photosynthesis which in turn might have increased the flower diameter. The highest number of flowers per plant and more production of flowers/plot as well as yield/ha might be due to the fact that the application of vermicompost increases good physical and biological conditions of soils which might have improved the physiology of plant to shift from vegetative to reproductive stage. Moreover, vermicompost enhances photosynthesis efficacy which may have enhanced food accumulation resulting in better plant growth and subsequently higher number of flowers per plant as well as yield (Sunitha et al. 2007). The increased production of flower in response to vermi-compost was attributed to a greater availability of mineral nutrient (Edward and Burrovs 1988). Similar results were also reported by Maniram et al. (2012 b) in gladiolus.

Application of salicylic acid showed significant differences among the treatments in terms of flowering parameters. Maximum number of flowers per plant (48.74) and number of flower per plot (1458.13) were recorded with foliar application of salicylic acid@100 ppm while minimum number of flowers/ plant (43.40) and number of flowers/ plot (1300.60) were noted in control. It might be due to that foliar spray of salicylic acid increased protein synthesis and appearance of new isozyme bands (Kumar and Nanda 1981). Chen et al. (1993) reported that salicylic acid inhibited the synthesis of catalase and accumulated of $\mathrm{H}_{2} \mathrm{O}$. Similar results were also reported by Handro et al. (1997) in Streptocarpus nobilis; Jabbarzadeh et al. (2009) in African violet. Application of SA $@ 100$ ppm produced larger size of flower $(5.76 \mathrm{~cm})$ whereas, control $\left(\mathrm{SA}_{0}\right)$ gave smaller size of flower $(4.76 \mathrm{~cm})$. Salicylic acid has positive effect on photosynthesis and carbohydrate in leaves and stem due to this reason flower size increased. The increase in flower diameter could be due to the synergism between salicylic acid and auxin. Similar results were obtained by Maniram et al. (2012) who recorded increase in flower diameter with application of salicylic acid in gladiolus. Flower yield attributing characters were significantly influenced by various concentrations of salicylic acid and differed each other. Maximum weight of individual flower (2.75 g) was recorded with SA @100 ppm followed by, $(2.41 \mathrm{~g})$ with $\mathrm{SA}_{2} @ 200$ ppm and minimum weight of individual flower (1.46 g) was recorded under control. Application of SA significantly increased the weight of flower by improving photosynthetic efficiency (Hayat and Ahmad 2007), stabilization of chlorophyll and assimilates translocation from source to sink which ultimately enhanced weight of flower (Choudhary et al. 2016). The results are in agreement with the work done by Naglaa et al. (2018) in Zinnia and Basit et al. (2018) in marigold. Maximum flower yield/ plant (135.03 g), flower yield/ plot $(4.00 \mathrm{~kg})$ and total flower yield/ha (3.11 ton/ha) had been observed with 100 ppm while, $\mathrm{SA}_{0}$ 
resulted in minimum flower yield/plant (83.36 g), flower yield /plot $(2.49 \mathrm{~kg})$ and total flower yield (1.93 ton/ha) respectively. SA enhances transcription and translation of mRNA and protein (Singh et al. 2002), that help in developing new groups of isozymes which enhance the number of flower buds (Bayat et al. 2012). These increases of flower buds/ plant ultimately increased number of flowers/plot as well as total flower yield/ha. Similar results were also reported by Gad et al. (2016) in Ixora plant.

Combined effect of spacing, doses of vermicompost and foliar application of salicylic acid on flower yield of chrysanthemum

The combined/interactions effect generated by planting spacing, doses of vermi-compost and foliar application of salicylic acid showed significant effect on flower yield attributes (Table 5). Maximum flower yield/plant (162.39 g) was recorded with treatment combination $\mathrm{T}_{26}\left(\mathrm{~S}_{3}+\mathrm{VC}_{2}+\mathrm{SA}_{1}\right)$. The increasing number of flower/plant might be due more plant space along with vermi-compost which provides more nutrients to the plant similarly, foliar application of salicylic acid increased protein synthesis and appearance of new isozyme bands resulted more number of flower/plant. However, treatment combination $\mathrm{T}_{8}\left(\mathrm{~S}_{1}+\mathrm{VC}_{2}+\mathrm{SA}_{1}\right)$ resulted in maximum flower yield/plot $(4.87 \mathrm{~kg})$ and flower yield (3.79 ton/ha). It might be due to more number of plants at particular area and higher doses of vermi-compost attributed to a greater availability of mineral nutrients to the plants while $100 \mathrm{ppm}$ foliar application of salicylic acid increased protein synthesis and appearance of new isozyme bands resulted more flower yield/ha.

Table 5: Combined impact of spacing, doses of vermi-compost and foliar application of salicylic acid on yield of chrysanthemum

\begin{tabular}{|c|c|c|c|}
\hline Treatment & & Yield of flower & \\
\hline Spacing $(\mathrm{cm})$ & Flower yield/plant(g) & Flower yield/plot(kg) & Total flower yield (ton $/ \mathrm{h}$ ) \\
\hline $\mathrm{T}_{1}\left[\mathrm{~S}_{1}+\mathrm{VC}_{0}+\mathrm{SA}_{0}(50 \times 50+0+0)\right]$ & 69.18 & 2.49 & 1.93 \\
\hline $\mathrm{T}_{2}\left[\mathrm{~S}_{1}+\mathrm{VC}_{0}+\mathrm{SA}_{1}(50 \times 50+0+100)\right]$ & 101.32 & 3.64 & 2.83 \\
\hline $\mathrm{T}_{3}\left[\mathrm{~S}_{1}+\mathrm{VC}_{0}+\mathrm{SA}_{2}(50 \times 50+0+200)\right]$ & 99.33 & 3.58 & 2.78 \\
\hline $\mathrm{T}_{4}\left[\mathrm{~S}_{1}+\mathrm{VC}_{1}+\mathrm{SA}_{0}(50 \times 50+5+0)\right]$ & 81.54 & 2.94 & 2.28 \\
\hline $\mathrm{T}_{5}\left[\mathrm{~S}_{1}+\mathrm{VC}_{1}+\mathrm{SA}_{1}(50 \times 50+5+100)\right]$ & 129.70 & 4.67 & 3.63 \\
\hline $\mathrm{T}_{6}\left[\mathrm{~S}_{1}+\mathrm{VC}_{1}+\mathrm{SA}_{2}(50 \times 50+5+200)\right]$ & 127.62 & 4.59 & 3.57 \\
\hline $\mathrm{T}_{7}\left[\mathrm{~S}_{1}+\mathrm{VC}_{2}+\mathrm{SA}_{0}(50 \times 50+10+0)\right]$ & 89.09 & 3.21 & 2.49 \\
\hline $\mathrm{T}_{8}\left[\mathrm{~S}_{1}+\mathrm{VC}_{2}+\mathrm{SA}_{1}(50 \times 50+10+100)\right]$ & 135.36 & 4.87 & 3.79 \\
\hline $\mathrm{T}_{9}\left[\mathrm{~S}_{1}+\mathrm{VC}_{2}+\mathrm{SA}_{2}(50 \times 50+10+200)\right]$ & 132.31 & 4.76 & 3.70 \\
\hline $\mathrm{T}_{10}\left[\mathrm{~S}_{2}+\mathrm{VC}_{0}+\mathrm{SA}_{0}(50 \times 60+0+0)\right]$ & 74.95 & 2.25 & 1.75 \\
\hline $\mathrm{T}_{11}\left[\mathrm{~S}_{2}+\mathrm{VC}_{0}+\mathrm{SA}_{1}(50 \times 60+0+100)\right]$ & 115.72 & 3.47 & 2.70 \\
\hline $\mathrm{T}_{12}\left[\mathrm{~S}_{2}+\mathrm{VC}_{0}+\mathrm{SA}_{2}(50 \times 60+0+200)\right]$ & 109.40 & 3.28 & 2.55 \\
\hline $\mathrm{T}_{13}\left[\mathrm{~S}_{2}+\mathrm{VC}_{1}+\mathrm{SA}_{0}(50 \times 60+5+0)\right]$ & 83.56 & 2.51 & 1.95 \\
\hline $\mathrm{T}_{14}\left[\mathrm{~S}_{2}+\mathrm{VC}_{1}+\mathrm{SA}_{1}(50 \times 60+5+100)\right]$ & 142.80 & 4.28 & 3.33 \\
\hline $\mathrm{T}_{15}\left[\mathrm{~S}_{2}+\mathrm{VC}_{1}+\mathrm{SA}_{2}(50 \times 60+5+200)\right]$ & 140.09 & 4.20 & 3.27 \\
\hline $\mathrm{T}_{16}\left[\mathrm{~S}_{2}+\mathrm{VC}_{2}+\mathrm{SC}_{0}(50 \times 60+10+0)\right]$ & 91.64 & 2.75 & 2.14 \\
\hline $\mathrm{T}_{17}\left[\mathrm{~S}_{2}+\mathrm{VC}_{2}+\mathrm{SA}_{1}(50 \times 60+10+100)\right]$ & 149.06 & 4.47 & 3.48 \\
\hline $\mathrm{T}_{18}\left[\mathrm{~S}_{2}+\mathrm{VC}_{2}+\mathrm{SA}_{2}(50 \times 60+10+200)\right]$ & 147.19 & 4.42 & 3.43 \\
\hline $\mathrm{T}_{19}\left[\mathrm{~S}_{3}+\mathrm{VC}_{0}+\mathrm{SA}_{0}(50 \times 75+0+0)\right]$ & 78.93 & 1.90 & 1.47 \\
\hline $\mathrm{T}_{20}\left[\mathrm{~S}_{3}+\mathrm{VC}_{0}+\mathrm{SA}_{1}(50 \times 75+0+100)\right]$ & 120.50 & 2.89 & 2.25 \\
\hline $\mathrm{T}_{21}\left[\mathrm{~S}_{3}+\mathrm{VC}_{0}+\mathrm{SA}_{2}(50 \times 75+0+200)\right]$ & 118.28 & 2.84 & 2.21 \\
\hline $\mathrm{T}_{22}\left[\mathrm{~S}_{3}+\mathrm{VC}_{1}+\mathrm{SA}_{0}(50 \times 75+5+0)\right]$ & 86.59 & 2.08 & 1.62 \\
\hline $\mathrm{T}_{23}\left[\mathrm{~S}_{3}+\mathrm{VC}_{1}+\mathrm{SA}_{1}(50 \times 75+5+100)\right]$ & 158.44 & 3.80 & 2.95 \\
\hline $\mathrm{T}_{24}\left[\mathrm{~S}_{3}+\mathrm{VC}_{1}+\mathrm{SA}_{2}(50 \times 75+5+200)\right]$ & 155.36 & 3.73 & 2.90 \\
\hline $\mathrm{T}_{25}\left[\mathrm{~S}_{3}+\mathrm{VC}_{2}+\mathrm{SA}_{0}(50 \times 75+10+0)\right]$ & 94.78 & 2.27 & 1.77 \\
\hline $\mathrm{T}_{26}\left[\mathrm{~S}_{3}+\mathrm{VC}_{2}+\mathrm{SA}_{1}(50 \times 75+10+100)\right]$ & 162.39 & 3.90 & 3.02 \\
\hline $\mathrm{T}_{27}\left[\mathrm{~S}_{3}+\mathrm{VC}_{2}+\mathrm{SA}_{2}(50 \times 75+10+200)\right]$ & 160.25 & 3.84 & 2.99 \\
\hline CD at $5 \%$ & 1.157 & 0.034 & 0.027 \\
\hline
\end{tabular}


Effect of spacing, doses of vermicompost and foliar application of salicylic acid on availability of NPK in post-harvested soil of chrysanthemum

Data presented in (Table 6) indicates that various spacing, gradual doses of vermicompost and different concentrations of salicylic acid had significant effect on availability of NPK in post harvested soil. The maximum nitrogen (146.76), phosphorus (24.22) and potassium (126.81) were recorded with wider spacing $(50 \times 75)$ however, closer spacing $(50 \times 50)$ had minimum nitrogen $(142.60 \mathrm{~kg})$, phosphorus $(20.46 \mathrm{~kg})$ and potassium $(123.00 \mathrm{~kg} /$ ha). It might be due that under wider spacing had less number of plant which absorbed low quantity of nutrients ultimately increased the availability of NPK in post harvested soil as compared to closer spacing. Similar results were also reported by Ingle et al. (2014) in sorghum.

Table 6: Impact of spacing, doses of vermi-compost and foliar application of salicylic acid on NPK of post-harvested soil of chrysanthemum

\begin{tabular}{cccc}
\hline Treatment & $\begin{array}{c}\text { Nitrogen } \\
\text { (kg/ha) }\end{array}$ & $\begin{array}{c}\text { Phosphorus } \\
\text { (kg/ha) }\end{array}$ & $\begin{array}{c}\text { Potassium } \\
\text { (kg/ha) }\end{array}$ \\
\hline Spacing $(\mathbf{c m})$ & & & \\
\hline $\mathrm{S}_{1}(50 \times 50)$ & 142.60 & 20.46 & 123.00 \\
$\mathrm{~S}_{2}(50 \times 60)$ & 144.65 & 22.30 & 124.85 \\
$\mathrm{~S}_{3}(50 \times 75)$ & 146.76 & 24.22 & 126.81 \\
\hline Vermi-compost & & & \\
(ton/ha) & & & \\
\hline VC $_{0}(0)$ & 134.09 & 17.12 & 115.13 \\
VC $_{1}(5)$ & 146.74 & 22.85 & 126.62 \\
VC $_{2}(10)$ & 153.17 & 27.81 & 132.90 \\
\hline Salicylic acid & & & \\
(ppm) & & & \\
\hline SA $_{0}(0)$ & 144.28 & 22.05 & 124.69 \\
SA $_{1}(100)$ & 142.99 & 20.75 & 123.09 \\
SA $_{2}(200)$ & 143.72 & 21.17 & 123.88 \\
CD at $5 \%$ & 0.102 & 0.026 & 0.148 \\
\hline
\end{tabular}

Various doses of vermicompost exhibited significant effect on NPK availability of post harvested soil. The maximum nitrogen $(153.17 \mathrm{~kg} / \mathrm{ha})$, phosphorus $(27.81 \mathrm{~kg})$ and potassium $(132.90 \mathrm{~kg} / \mathrm{ha})$ was recorded when plants were treated with $\mathrm{VC}_{2}(10 \mathrm{ton} /$ ha) while control $\mathrm{VC}_{0}$ resulted in minimum nitrogen (134.09 kg/ha), phosphorus (17.12 kg/ha) and potassium $(115.13 \mathrm{~kg} / \mathrm{ha})$ during course of study. The higher values of NPK in post-harvested soil under the treatment $\mathrm{VC}_{2}$ may be due to additional supply of nutrients in the soil by vermi-compost and lower availability of $\mathrm{NPK}$ in treatment $\mathrm{VC}_{0}$ might be due to more absorption of nutrients. Similar findings reported by Tiwari et al. (2018 a) in marigold.

Different concentrations of salicylic acid differed each other among the treatments in terms of availability of NPK in post harvested soil. The plants sprayed without any salicylic acid had maximum nitrogen $(144.28 \mathrm{~kg} / \mathrm{ha})$, phosphorus $(22.05 \mathrm{~kg} /$ ha) and potassium (124.69 $\mathrm{kg} / \mathrm{ha})$ on the other hand minimum available nitrogen $(142.99 \mathrm{~kg} / \mathrm{ha})$, phosphorus (20.75 kg/ha) and potassium (123.09 $\mathrm{kg} / \mathrm{ha}$ ) were recorded with foliar application of salicylic acid@100 ppm. It might be due to that SA in lower quantity stimulated of root formation in young shoots of ornamental plants (Singh 1993). This positive effect could be explained upon the effect of SA on increasing $\mathrm{CO}_{2}$ assimilation and accordingly photosynthetic rate in addition to the increase in mineral uptake (Karlidage et al. 2009).

\section{CONCLUSION}

On the basis of results obtained from the present investigation, it can be concluded that closer spacing $(50 \times 50 \mathrm{~cm}), 10$ ton/ha of vermi-compost and $100 \mathrm{ppm}$ of salicylic acid is optimum cultural activities for better growth and higher flower yield in chrysanthemum.

\section{ACKNOWLEDGEMENTS}

Authors greatly acknowledge the support and encouragement of Professor R.K Mittal Hon'ble Vice Chancellor of Sardar Vallabhbhai Patel University of Agriculture \& Technology, Meerut (U.P.), India.

\section{REFERENCES}

Al-Hasnawi, H.A., Hussein, J.K. and Khaleel, T.H. 2019. Effect of growth regulators and preservative solution on vase life and water relation of gladiolus hybrida l. after cut flowers. Iraqi Journal of Agricultural Sciences, 50(Spl): 182-191.

Baboo, R., Ahamad, N. and Singh, D. 2005. Growth and flowering of African marigold (Tagetes erecta L.) as affected by Nitrogen and Phosphorus under varying intra-row spacings. Journal of Ornamental Horticulture, 8(4): 312-313.

Barakan, F.N., Salem, S.H., Heggo, A.M. and Binshiha, M.A. 1995. Activities of rhizosphere microorganism as affected $\backslash$ by application of organic amendments in a calcareous loamy soil 2. Nitrogen transformation. Arid Soil Research and Rehabilization, 9(4): 467-480. 
Barman and Pal, P. 1999. Effect of nitrogen, potassium and spacing on growth and flowering of chrysanthemum (Chrysanthemum morifolium Ramat) Cv 'Chandrama'. Horticulture Journal, 12(1): 51-9.

Basit, A., Shah, K., Rahman, M.U., Xing, L., Zuo, X., Han, M., Alam, N., Khan, F., Ahmed, I. and Khalid, M.A. 2018. Salicylic acid an emerging growth and flower inducing hormone in marigold (Tagetes sp). Pure Appl. Bio., 7(4): 1301-1308.

Bayat, H., M. Alirezaie and Neamati, H. 2012. Impact of exogenous salicylic acid on growth and ornamental characteristics of calendula (Calendula officinalis L.) under salinity stress. Journal of Stress Physiology E Biochemistry, 8(1): 258-267.

Bentize, E.R., Nogales, G. and Ceccanth, M. 2000. Isolation by isoelectric focusing of humic ureas complex from earthworm Eisenia foetida proceed sewage sludge. Biol. Fert. Soil, 31: 489-493.

Bhalla, R., Shivakumar, M.H. and Jain R. 2007. Effect of organic manures and biofertilizers on growth and flowering in standard carnation (Dianthus caryophyllus L.). J. of Orn. Hort., 10: 229-34

Bhande, M.H., Chopde, N., Lokhande, S. and Wasnik P. 2015. Effect of spacing and corm size on growth, yield and quality of gladiolus. Plant Archives, 15(1): 541-544.

Blake, G.R. 1965. Bulk Density. In: Methods of Soil Analysis. Agronomy Journal. 9 (Part 11, C.A. Black, ed.) pp. 374-390.

Charles, F.C. and Tanaka, O. 1979. Effect of day length of the ability of salicylic acid to induce flowering in the long day plant Lemna gibb G3 and the short day plant Lemna paucicostata 6746. Plant Physiology, 64: 421-424.

Chen, Z.X., Silva, H. and Klessig, D. 1993. Active oxygen species in the induction of plant systemic acquired resistance by salicylic acid. Science, 226: 1883-1886.

Choudhary, A., Mishra, A., Bola, P., Moond, S. and Dhayal, M. 2016. Effect of foliar application of zinc and salicylic acid on growth, flowering and chemical constitute of African marigold cv. pusa narangi gainda (Targets erecta L.). J. Appl. Nat. Sci., 8: 1467-1470.

Cleland, C.F. and Ajami, A. 1974. Identification of flower inducing factor isolated from aphid honeydew as being salicylic acid. Plant Physiology, 54: 904- 906.

Cleland, C.F., Tanaka, O. and Feldman, L.J. 1982. Influence of plant growth substances and salicylic acid on flowering and growth in the Lemnaceae(duckweed). Aquatic Botany, 13: 320-325.

Critto, M. and Vita, M. 1980. A comprision of three different planting density for increasing the size of gladiolous corm. Annnali-della Institute sperimentale-La-Floricnltura 11(1): 189-194.

Dorajeerao, A.V.D. and Mokashi, A.N. 2013. Growth analysis as influenced by planting geometry in garland chrysanthemum (Chrysanthemum coronarium L.) Global Journal of Bio-Science and Biotechnology, 2(1): 21-26.

Edward, C.A. and Burrovs, I. 1988. The potential of earthworm compost as plant growth media. In Edward
CA Neuhauson (eds) Earthworm in in environmental and waste Management, SPB Acadmic Publ. by The Neatherlands, pp. 211-220.

Follet, R., Donahue, R., and Murphy, L. 1981. Soil and soil amendments. Prentice- Hall, Inc, New Jersey.

Gad, M.M., Abdul-Hafeez, E.Y. and Ibrahim, O.H.M. 2016. Foliar application of salicylic acid and gibberellic acid enhances growth and flowering of Ixora coccinea L. plants. J. Plant Production, Mansoura Univ., 7: 85-91.

Han, J., Sun, L., Dong, X., Cai, Z., Yang, W., Wang, W. and Sang, W. 2005. Charectarization of a novel plant growth bacteria strain Delftia tsuruhatensis HR4 both as a diazotroph and a potential biocontrol agent against various pathogens. Systmatic Applied Microbiology, 28: 66-76.

Handro, W., Mello, C.M, Manzano, M.A. and Floh, E.I.S. 1997. Enhancement of stem elongation and flower bud regeneration by salicylic acid. R. Bras. Fisiol. Veg., 9(1): 139-142.

Hayat, Q., Shah, H. Muhammad, I. and Alam, A. 2010. Effect of exogenous salicylic acid under changing environment, A review Environmental and Experimental Botany, 68: 14-25.

Hayat, S. and Ahmad, A. 2007. Salicylic acid: a plant hormone. Springer, pp. 401.

Ingle, S.S., D. Jadhao, V.K. Kharche, B.A. Sonune and Mali, D.V. 2014. Soil biological properties as influenced by longterm manuring and fertilization under sorghum (Sorghum bicolor) -wheat (Triticum aestivum) sequencein Vertisols. Indian Journal of Agri. Sc., 84(4): 452-457.

Jabbarzadeh, Z., Khosh-Khui, M. and Salehi, H. 2009. The effect of foliar applied salicylic acid on flowering of African violate, Australian Journal of Basic and Applied Sciences, 3(4): 4693- 4696.

Jackson, M.L. 1973. Soil Chemical analysis. Prentice Hall India Pvt. Ltd. New Delhi.

Kamkari, B., Asgharzadeh, A. and Azimzadeh, M. 2016. Effects of salt stress and salicylic acid on vegetative and reproductive traits of pot marigold. $I I O A B J, 7(S)$ : 34-41.

Karavadia, B.N. and Dhaduk, B.K. 2002. Effect of spacing and nitrogen on annual chrysanthemum (Chrysanthemum coronarium) Cv. Local white. Journal of Ornamental Horticulture, 5(1): 65-66.

Karlidag, H., Yildirim, E. and Turan, M. 2009. Salicylic acid ameliorates the adverse effect of salt stress on strawberry. Sci. Agric., 66: 180-187

Khalaj, M.A., Edrisi, B. and Amiri, M. 2012. Effect of nitrogen and plant spacing on nutrients uptake, yield and growth of tuberose (Polianthes tuberosa L.). Journal of Ornamental and Horticultural Plants, 2(1): 45-54.

Khandaker, L., Akond, A.M. and Shinya, O.B.A. 2011. Foliar application of salicylic acid improved the growth, yield and leaf's bioactive compounds in red amaranth (Amaranthus tricolor L.). Vegetable Crops Research Bulletin, 74: 77-86.

Khurama, J.P. and Cliland, C.F. 1992. Role of Salicylic acid and Banzoic acid in flowering of a photo period in sensitive 
strain, Limna paucicostola LP 61. Plant Physiology, 100: 1541-1546.

Kour, R. 2009. Flowering production as effected by spacing and pinching in chrysanthemum cv. Flirt; International Journal of Agriculture Science, 5(2): 588-589.

Kumar, A., Prakash, C.H., Brar, N.S. and Kumar, B. 2018. Potential of vermicompost for sustainable crop production and soil health improvement in different cropping systems. Int. J. Curr. Microbiol. App. Sci., 7(10): 1042-1055.

Kumar, M. 2014. Effect of different sources of nutrients on growth and flowering in gladiolus (Gladiolus hybridus Hort.) cv. Peater Pears. Annals of Horticulture, 7(2): 154-158.

Kumar, M. 2014. Effect of different sources of nutrients on growth and flowering in tuberose (Polianthes tuberosa 1.) cv. "Vaibhav". Progressive Research, 9(Special): 872-875.

Kumar, M. 2015. Flower and corm production in gladiolus (Gladiolus hybridus Hort.) cv. "Peater pears" as influenced by different nutrients sources. Annals of Horticulture, 8(1): 99-102.

Kumar, S. and Nanda, K.K. 1981. Gibbrellic acid and salicylic acid caused formation of new proteins associated with extension growth and flowering of Impatiens balsamina. Biologia Plantarum, 23: 321-327.

Mackay, W.A., Shankla, N., Shankla, D. and Devis, T.D. 2000. Post-harvest performance of Lupin shavardil watts; a new cut flower crop. Lupin, an ancient crop for the new millennium: proceedings of the $9^{\text {th }}$ Int. Lupin conference, Klink Muritz, Germany, pp. 330-332.

Maniram, Pal, V., Singh, M.K. and Kumar, M. 2012a. Response of different spacing and salicylic acid levels on growth and flowering of gladiolus (Gladiolus grandiflorus L). Hortflora Research Spectrum, 1(3): 270-273.

Maniram, Kumar, M., Malik, S., Singh, M.K. and Pal, V. 2012b. Impact of Spacing, doses of Vermi- Compost and foliar application Salicylic Acid on Growth and Flowering of Gladiolus (Gladiolus Grandiflorus L.) Cv. "White Prosperity" Annals of Horticulture, 5(2): 272-279.

Martin, R.E., Villaneuva, T., Herrera, A. and Larque, S. 2005. Positive effect of salicylate on the flowering of African violates. Scientia Hort., 103: 499-502.

Martinez, C., Pons, E., Guillermo, P. and Leon, J. 2004. Salicylic acid regulates flowering time and links defense responses and reproductive development. The Plant Journal, 37: 209-217.

Naglaa, F.S. Elbohy, K.E. Attia and Noor El-Deen, T.M. 2018. Increasing quality of Zinnia elegans plants by foliar spraying with ascorbic and salicylic acids. Middle East Journal of Agriculture Research, 7(4): 1786-1797.

Navale, M.U., Aklade, S.A., Desai, J.R. and Nannavare, P.V. 2010. Influence of plant regulators on growth, flowering and yield of chrysanthemum (Dendranthema grandiflora Tzvelev) cv. IIHR-6. International Journal of Pharma and Bio Sciences, 1(2). 7-11.

Neilsan, R.L. 1985. Presence of plant growth substances in earthworm demonstrate by paper chromatography and the Went pea Test. Nature, 208(5015): 1113-1114.
Olsen, S.R., Cob, V.V., Watanabe, F.S. and Dean, L.A. 1954. Estimation of available phosphorus in soils by extraction with sodium bicarbonate. U.S. Dept. Agric. Washington, D.C. Circ. 939.

Padaganur, A.N. Mokashi, A.N. and Patil V.S. 2005. Flowering, flower quality and yield of tuberose (Polianthes tuberosa L.) as influenced by vermicompost farmyard manure and fertilizers. Karnataka Journal of Agriculture Science, 18(3): 729-734.

Pal, A. and Pandey AK. 2007. Effect of plant spacing on growth and flowering in African marigold (Tagetes erecta L.) under Bundelkhand region. Prog. Res., 2(1, 2): 70-72.

Pal, V., Maniram and Kumar, M. 2015. Effect of various levels of spacing and salicylic acid treatment on vegetative growth and flowering of gladiolus (Gladiolus grandiflora 1.$)$ cv. White prosperity. South Asian J. Food Technol. Environ. 1(1): 101-104.

Prasad, R., Shivay, Y.S. Kumar, D. and Sharma, S.N. 2006. Learning by doing exercise in soil fertility - a practical manual for soil fertility. Division of Agronomy, IARI, New Delhi.

Rahmani, I.N. Ahmadi, F. Ghanati, and Sadeghi, M. 2015. Effects of salicylic acid applied pre or post-transport on post-harvest characteristics and antioxidant enzyme activity of gladiolus cut flower spikes. New Zealand J. Crop and Hort. Sci., 43(4): 294-305.

Raskin, I. 1992. Role of Salicylic acid in plants. Annual Rev. Plant Physiol Plant Mol. Bio., 43: 439-463.

Roodbarak, F. Hashemabadi, D. and Vand, S.H. 2012. Effect of salicylic acid on vase life of cut carnation (Dianthus caryophyllus. L. cv. 'Liberty Abgr'). Ann. Biol. Res., 3: 5127-5129.

Sainz, M.J., Taboada, C. and Vilarino, A. 1998. Growth mineral nutrition and micorrihizal colonization of red clover and cucumber plants grown in soil amended with composted urban wastes. Plant and Soil, 205: 85-92.

Sarek, M. 1992. Does salicylic acid effect of the post harvest characteristics of Comaniulla carpetica? Gartenbauwissenschaft, 57: 112-114.

Shivakumar, C.M. 2000. Effect of mother plant nutrition, plant density and seed maturity on seed yield and quality in marigold. M.Sc (Agri) Thesis. University of Agricultural sciences, Dharwad.

Simard, R.R. 1993. Ammonium acetate extractable elements. In: Martin, R., Carter, S., (eds), Soil Sampling and Methods of Analysis. Lewis Publisher, Florida, USA., pp. 39-43.

Singh, K.B., Foley, R.C. and Oñate-Sánchez, L. 2002. Transcription factors in plant defense and stress responses. Curr. Opin. Plant Biol., 5: 430-436.

Singh, M., Dwivedi, D.H. and Kumar, M. 2015. Effeciency of organic and biodynamic manures on growth and flowering in marigold (Tagetes patula L.) Progressive Agriculture, 15(1): 134-137.

Singh, M.K., Kumar, V., Malik, S., Kumar, M. and Kumar, U. 2010. Response of organic and inorganic fertilizers on 
growth and yield of chilli (Capsicum annum L.) cv. Pant C-1. Annals of Horticulture, 3(1): 122-123.

Singh, P., Prakash, S., Kumar, M., Kumar, S. and Singh, M.K. 2015. Effect of integrated nutrient management (INM) on growth, flowering and yield of marigold (Tagetes erecta L.), Pusa Basanti. Annals of Horticulture, 8(1): 73-80.

Singh, R., Kumar, M., Raj, S. and Kumar, S. 2013. Effect of Integrated Nutrient Management (INM) on growth and flowering in gladiolus (Gladiolus grandiflorus L.) cv. "White Prosperity. Annals of Horticulture, 6(2): 242-251.

Singh, S.P. 1993. Effect of non-auxinic chemicals on root formation in some ornamental plant cuttings. Adv. Hortic Flor., 3: 207-210.

Singh, L., Gurjar, P.K.S. Barholia, A.K. Haldar, A. and Shrivastava, A. 2015. Effect of organic manures and inorganic fertilizers on \growth and flower yield of marigold (Tagetes erecta L.) Var. Pusa narangi gainda. Plant Archives, 15(2): 779-783.

Srivastava, S.K., Singh, H.K. and Srivastava, A.K. 2002. Study on spacing and pinching on growth and flowering of 'Pusa Narangi Gainda' marigold (Tagetes erecta L.). Indian Journal of Agricultural Sciences, 72: 611-612.

Sunitha, H.M., R. Hunje, B.S. Vyakaranahal and Ablad, H.B.B. 2007. Effect of plant spacing and integrated nutrient management on yield and quality of seed and vegetative growth parameters in African marigold (Tagetes erecta Linn.). J. Orna. Hort., 10(4): 245-249.
Tiwari, H., Kumar, M. and Naresh, R.K. 2018a. Effect of nutrient management and gibberellic acid on growth, flowering and nutrients availability in post-harvested soil of Marigold (Tagetes erecta L.) cv. Pusa Narangi Gainda. International Journal of Chemical Studies, 6(4): 510-514.

Tiwari, H., Kumar, M., Naresh, R.K., Singh, M.K., Malik, S., Singh, S.P. and Chaudhary, V. 2018 b. Effect of organic and inorganic fertilizers with foliar application of gibberellic acid on productivity, profitability and soil health of marigold (Tagetes erecta L.) cv. Pusa Narangi Gainda. Int. J. Agricult. Stat. Sci., 14(2): 575-585.

Vinayk, K., Prasad, V.M., Sindhuja, M., Rajawade, V.B. and Singh, D. 2017. Response of spacing and nitrogen levels on growth and flowering of salvia (Salvia splendens L.). Journal of Pharmacognosy and Phytochemistry, 6(4): 2059-2062.

Vomocil, J.A. 1965. Porosity in methods of Soil Analysis: Physical and Mineralogical properties, including statistics of measurement and sampling. Agronomy, part-1, No. 9, American Agronomy Society, Madison, WI.

Walkley, A. and Black, I.A. 1934. An examination of Degtjareff method for determining soil organic matter, and a proposed modification of the chromic acid titration method. Soil Sci., 37: 29-38.

Zink, T.A. and Allen, M.F. 1998. The effect of organic amendments on the restoration of a disturbed coastal sage scrub habital. Restor. Ecol., 6: 52-58. 